\title{
Studies on Nutrient Partitioning in Mango (Mangifera indica L.)
}

\author{
Devang Khalasi ${ }^{1}$, A.K. Pandey ${ }^{1}$ and Sanjeev Kumar ${ }^{2 *}$ \\ ${ }^{1}$ Department of Fruit Science, ${ }^{2}$ Department of Vegtable Science, ASPEE College of \\ Horticulture and Forestry, Navsari Agricultural University, Navsari-396 450 (Gujarat), India \\ *Corresponding author
}

\section{A B S T R A C T}

\section{Keywords \\ Mango varieties peel, Pulp, Kernel, Nutrients and accumulation \\ Article Info \\ Accepted: \\ 18 August 2018 \\ Available Online: \\ 10 September 2018}

An experiment was carried out to investigation mango fruit of variety Kesar, Alphonso, Sonpari and Totapuri were collected at Harvest stage and different part peel, pulp and kernel for estimation of macronutrients ( $\mathrm{N}, \mathrm{P}, \mathrm{K}, \mathrm{Ca}, \mathrm{Mg}$ and $\mathrm{S}$ ) and micronutrients ( $\mathrm{Zn}$, $\mathrm{Fe}, \mathrm{Mn}$ and $\mathrm{Cu}$ ). Nutrient partitioning at harvest stage is revealed maximum $\mathrm{N}(2.29 \%)$, $\mathrm{Mg}(0.22 \%)$ and $\mathrm{S}(0.36 \%)$ content were in peel and highest $\mathrm{Ca}(0.80 \%)$ accumulation in pulp of Kesar variety. The Sonpari variety found maximum P $(0.30 \%)$, Fe (150.60 ppm), $\mathrm{Mn}(17.58 \mathrm{ppm})$ and $\mathrm{Cu}(63.94 \mathrm{ppm})$ accumulation in kernel of fruit. While $\mathrm{K}(1.07 \%)$ and $\mathrm{Zn}(92.00 \mathrm{ppm})$ was recorded higher in pulp of Totapuri and Sonpari variety, respectively.

\section{Introduction}

Mango (Mangifera indica L.) belongs to the family Anacardiaceae, originating in South East Asia. Mango is one of the major fruits of Asia and has developed its own importance all over the world. It is also a good source of $\beta$ carotene i.e. vitamin-A, $\mathrm{B}$ complex and $\mathrm{C}$, nutritive minerals, digestive sugars and trace elements. Its taste, flavour and aroma are very fascinating to everyone. Because of these naturally built in qualities, mango has gained now global popularity.

Mango having good nutritional value as every $100 \mathrm{~g}$ of mango fruit contains $81.7 \mathrm{~g}$ water, 16 $\mathrm{g}$ carbohydrate, $0.7 \mathrm{~g}$ protein, $0.4 \mathrm{~g}$ fat and 0.1 $\mathrm{g}$ fibers. It is rich in calcium, phosphorus, iron, magnesium, and also full of anti-oxidants. A single fruit can provide up to $40 \%$ daily dietary fiber needs (Chandra and Chandra, 1997). Mango kernel decoction and powder are used as vermifuges and astringents in diarrhoea, hemorrhages and bleeding hemorrhoids. Extracts of unripe fruits as well of bark, stems and leaves have shown antibiotic activity. Dried flowers are of medicinal value and used for curing dysentery and cattarah of bladder. It is a cure for wasp sting, rubbed between hands and left to dry. Mango fruit is one of the delicious fruit of India exported too many countries. The green unripe fruits are used in curries, sharbats and pickles. 
The information is available on variation in nutrient content among different variety of mango during various growth stages is very meager. In order to avoid misleading soil fertility program, reference value used for interpreting the results of plant analysis should reliably reflect differences in nutrient content among very closely related plants. This is specially important for establishing and maintaining a proper fertilization in the orchards (Basar, 2006). Hence the present study was therefore proposed to establish proper nutrient management for mango in respect of nutrient accumulation in peel, pulp and kernel of mango cultivars.

\section{Materials and Methods}

\section{About the location}

This investigation was carried out at Regional Horticultural Research Station, Navsari Agricultural University, Navsari which is situated on the coast of Arabian sea at $20^{\circ}$ $57^{\prime} \mathrm{N}$ latitude and $72^{\circ}-54^{\prime} \mathrm{E}$ longitude at an altitude of about 10 meters above the mean sea level. The campus is about $12 \mathrm{~km}$ away from Dandi, a historical place near the Arabian seashore. The experiment was carried out at Regional Horticultural Research Station, ASPEE College of Horticulture and Forestry, Navsari Agricultural University, Navsari, Gujarat during 2016-17.

\section{Treatment details}

The experiment was laid out in Completely Randomized Design (with factorial concept) with 12 treatment combinations and 3 repetitions. The treatments comprised of four varieties $\left(\mathrm{V}_{1}\right.$ : Kesar, $\mathrm{V}_{2}$ : Alphonso, $\mathrm{V}_{3}$ : Sonpari and $\mathrm{V}_{4}$ : Totapuri) and three fruit component ( $\mathrm{P}_{1}$ : Peel, $\mathrm{P}_{2}$ : Pulp and $\mathrm{S}_{3}$ : Kernel) with the objectives of find out nutrient partitioning at harvest stages in different varieties namely Kesar, Aphonso, Sonpari and
Totapuri with respect to following observation.

Primary, Secondary and Micronutrient in fruit parts at harvest stage

\section{Methodology of nutrient analysis}

The numbers of fruits were collected at harvest stage for nutrient estimation in each variety is 5-10. N, P and $\mathrm{K}$ analysed by Jackson (1967), Ca, Mg by Cheng and Bray (1951) and $\mathrm{Zn}, \mathrm{Fe}, \mathrm{Mn}$ and $\mathrm{Cu}$ by Elwell and Gridley (1967) method. The data on various parameters namely primary nutrients (\%), Secondary (\%) and Micronutrients (ppm) were recorded as per the standard procedures and the mean values were subjected to statistical analysis as per procedure laid down by Panse and Sukhatme (1985).

\section{Results and Discussion}

The nutrients accumulation and their distribution in various parts of fruit at harvest stage is illustrated as mean values with statistical notation in the Table 1 and figure 1 , 2 and 3.

\section{Primary nutrients (N, P and K)}

The data indicated that the nitrogen content was significantly maximum in the peel (2.29 $\%$ ) of Kesar. This result is in close conformity of Aquino et al., (2014) who observed nutrient content in peel and pulp of banana cultivars. However, the phosphorus content was highest $(0.30 \%)$ in kernel of Sonpari. In contrary to phosphorus and nitrogen, the potassium content was observed highest in pulp (1.07\%) of Totapuri variety. It might be due to its assimilation or absorption by tissue (Rachel et al., 2014). This difference in the nutrient content of fruit parts was pointed towards their selected distribution among variety. This result is in conformity of Zavalloni et al., 
(2001) who study dynamics of $\mathrm{Ca}, \mathrm{Mg}$ and $\mathrm{K}$ into apple fruit.

\section{Secondary nutrients (Ca, Mg and S)}

Among different varieties calcium content was significantly maximum $(0.80 \%)$ in the pulp of Kesar. This results was linear with the findings of Simmons et al., (1998) who also study the effect of leaf to fruit ratio on mango. The highest magnesium $(0.22 \%)$ content was recorded in peel of Kesar and kernel of Alphonso. While sulphur content was noticed to be significantly maximum $(0.36 \%)$ in peel of Kesar and Totapuri. It was showed that content of secondary nutrients is in lesser concentration than primary nutrients. It might be due to more mobility of primary nutrients
$(\mathrm{N}, \mathrm{P}$ and $\mathrm{K}$ ) in comparison $\mathrm{Ca} \mathrm{Mg}$, and $\mathrm{S}$ it moves more rapidly in phloem and readily translocated to the meristamatic tissue and allow meristametic activity and to expand tissues thus required in more amount.

The present finding is in close conformity of the Clark and Smith (1990) who studied that nutrients are not always distributed uniformly between structural parts of persimmon fruit. Singh et al., (2015) also reported high nitrogen and magnesium in peel of grapefruit. Tongleaw et al., (2012) also recorded higher concentration of nitrogen in flavedo followed by pulp of pummelo fruit. Similaly, Storey and Treeby (1999) also noticed higher concentration of potassium in pulp than rind of Navel orange fruit.

Table.1 Interaction effect of different varieties and stages on accumulation of primary, secondary and micronutrients $\left(\mathrm{P}_{1}\right.$ - Peel, $\mathrm{P}_{2}$-Pul pand $\mathrm{P}_{3}$-Kernel)

\begin{tabular}{|c|c|c|c|c|c|c|c|c|c|c|}
\hline & \multicolumn{3}{|c|}{$\begin{array}{c}\text { Primary nutrients } \\
\text { Treatments }\end{array}$} & \multicolumn{3}{|c|}{$\begin{array}{c}\text { Secondary nutrients } \\
\text { (\%) }\end{array}$} & \multicolumn{3}{|c|}{ Micronutrients (ppm) } \\
\hline & $\mathbf{N}$ & $\mathbf{P}$ & $\mathbf{K}$ & $\mathbf{C a}$ & $\mathbf{M g}$ & $\mathbf{S}$ & $\mathbf{Z n}$ & $\mathbf{F e}$ & $\mathbf{M n}$ & $\mathbf{C u}$ \\
\hline $\mathbf{V}_{\mathbf{1}} \mathbf{P}_{1}$ & 2.29 & 0.17 & 0.44 & 0.07 & 0.22 & 0.36 & 16.20 & 83.42 & 4.36 & 33.99 \\
\hline $\mathbf{V}_{\mathbf{1}} \mathbf{P}_{2}$ & 1.57 & 0.18 & 0.55 & 0.80 & 0.18 & 0.24 & 20.11 & 37.45 & 4.99 & 52.58 \\
\hline $\mathbf{V}_{\mathbf{1}} \mathbf{P}_{3}$ & 1.15 & 0.20 & 0.45 & 0.03 & 0.16 & 0.08 & 25.44 & 51.02 & 7.20 & 43.22 \\
\hline $\mathbf{V}_{2} \mathbf{P}_{1}$ & 1.89 & 0.22 & 0.48 & 0.05 & 0.17 & 0.04 & 15.54 & 54.76 & 6.37 & 26.45 \\
\hline $\mathbf{V}_{2} \mathbf{P}_{2}$ & 0.90 & 0.19 & 0.79 & 0.56 & 0.18 & 0.18 & 21.98 & 78.10 & 10.63 & 27.57 \\
\hline $\mathbf{V}_{2} \mathbf{P}_{3}$ & 0.67 & 0.19 & 0.41 & 0.03 & 0.22 & 0.33 & 18.23 & 38.51 & 12.52 & 21.11 \\
\hline $\mathbf{V}_{3} \mathbf{P}_{1}$ & 1.41 & 0.24 & 0.46 & 0.04 & 0.14 & 0.17 & 20.14 & 114.01 & 4.08 & 38.41 \\
\hline $\mathbf{V}_{3} \mathbf{P}_{2}$ & 1.55 & 0.22 & 0.71 & 0.44 & 0.12 & 0.14 & 92.00 & 35.10 & 17.53 & 36.54 \\
\hline $\mathbf{V}_{3} \mathbf{P}_{3}$ & 1.19 & 0.30 & 0.43 & 0.05 & 0.13 & 0.15 & 21.10 & 150.60 & 17.58 & 63.94 \\
\hline $\mathbf{V}_{4} \mathbf{P}_{1}$ & 1.25 & 0.08 & 0.43 & 0.03 & 0.19 & 0.36 & 12.32 & 72.46 & 3.36 & 31.11 \\
\hline $\mathbf{V}_{4} \mathbf{P}_{2}$ & 1.28 & 0.18 & 1.07 & 0.62 & 0.11 & 0.35 & 28.00 & 63.50 & 12.34 & 20.06 \\
\hline $\mathbf{V}_{4} \mathbf{P}_{3}$ & 1.22 & 0.26 & 0.46 & 0.06 & 0.11 & 0.12 & 11.02 & 78.33 & 4.99 & 40.19 \\
\hline $\mathbf{C D}_{0.05}$ & 0.10 & 0.02 & 0.04 & 0.02 & 0.02 & 0.014 & 2.75 & 3.14 & 0.62 & 2.43 \\
\hline & & & & & & & & & \\
\hline
\end{tabular}

Micronutrients ( $\mathrm{Zn}, \mathrm{Fe}, \mathrm{Mn}$ and $\mathrm{Cu})$

Amongst micronutrient, zinc was accumulated significantly maximum (92.00 ppm) in pulp of Sonpari. The iron, copper and manganese content was recorded to be higher in kernel of
Sonpari viz., $150.60 \mathrm{ppm}, 63.94 \mathrm{ppm}$ and 17.58 ppm respectively. It might be due to all three nutrients was considered to have intermediate phloem mobility. The nutrient variation among fruit parts is due to genetic factor and different translocation ability. This results was confirmed 
with the finding of Singh et al., (2015) who conduct experiment on changes of minerals in fruit peel and pulp of grapefruit. Similarly, Salah and Dilshad (2001) also recorded higher copper concentration in seed than peel of pomegranate fruit.

On the basis of result obtained in the present investigation it can be inferred that nutrient partitioning at harvest stage is revealed maximum $\mathrm{N}, \mathrm{Mg}$ and $\mathrm{S}$ content were in peel and highest $\mathrm{Ca}$ content in pulp of Kesar variety. The Sonpari variety found maximum $\mathrm{P}, \mathrm{Fe}, \mathrm{Mn}$ and $\mathrm{Cu}$ content in kernel of fruit. While $\mathrm{K}$ and $\mathrm{Zn}$ was recorded higher in pulp of Totapuri and Sonpari variety respectively.

\section{References}

Anonymous (2017). Indian Horticulture Data base, National Horticulture Board, Ministry of Agriculture, Government of India.

Aquino, C. F. et al., (2014). Mineral content in the pulp and peel of banana cultivars. Pesquisa Agropecuaria Brasileira, 49(7): 546-553.

Chandra, A. and Chandra, A. (1997). Production and Postharvest Technology of Fruits, NBS pub. and Distributors, Bikaner, India.

Cheng, X. L and Bray, R. H. (1951). Determination of calcium and magnesium in soil and plant material. Soil Sci., 72:42.

Clark, C. J. and Smith, G. S. (1990). Seasonal changes in the composition, distribution and accumulation of mineral nutrients in persimmon fruit. Sci. Horti., 42: 85-97.

Elwell, W. T. and Gridley, J. A. F. (1967). In: Atomic absorption spectrophotometery, Pergamon Press Ltd., London, pp. 221.
Jackson, M.L. (1967). Soil chemical analysis, Asia Publishing House, Bombay.

Maiman, S and Dilshad A. (2002). Changes in physical and chemical properties during pomegranate (Punica granatum L.) fruit maturation. Food Chemistry, 76: 437-441.

Panse, V. G. and Sukhatme, P. V. (1967). Statistical methods for agricultural workers, Indian Council of Agricultural Research, New Delhi, India.

Rachel, A. et al., (2013). Assessment of physicochemical and mineral characters of the orange (Citrus sinensis) peels. J. of Asian Sci. Res., 3(12): 1181-1190.

Simmons, S.L. et al., (1998). Effects of leaf to fruit ratios on mango (Mangifera indica L. 'Kensington') fruit growth, nutrition and quality. Acta Horti., 46(3): 47-52.

Singh S. et al., (2015). Changes of minerals in fruit peel and pulp of grapefruit (Citrus paradise Macf.) cv. Star Ruby during fruit development. Res. on Crops, 16 (4): 669-674.

Storey, R. and Treeby, M. T. (2000). Seasonal changes in nutrient concentration of navel orange fruit. Sci. Horti., 84: 67-82.

Sun, Y. et al., (2015). Standardization of leaf sampling technique in jackfruit nutrient status diagnosis. Agric. Sci., 6(02): 232237.

Tongleaw, S. et al., (2012). Analysis of 'Khao Yai' Pummelo Fruit to estimate nutrient losses through crop removal. Kasetsart J., 46: 827-836.

Zavalloni, et al., (2001). Dynamics of uptake of calcium, potassium and magnesium into apple fruit in a high density planting. Acta Horti., 564(12): 113-121.

\section{How to cite this article:}

Devang Khalasi, A.K. Pandey and Sanjeev Kumar. 2018. Studies on Nutrient Partitioning in Mango (Mangifera indica L.). Int.J.Curr.Microbiol.App.Sci. 7(09): 2793-2796. doi: https://doi.org/10.20546/ijcmas.2018.709.346 